\title{
The dependence of water potential in shoots of Picea abies on air and soil water status
}

\author{
A. Sellin \\ Department of Botany and Ecology, University of Tartu, Lai 40, EE 2400 Tartu, Estonia, E-mail: arne@zbi.ee
}

Received: 21 May 1997 / Revised: 6 October 1997 / Accepted: 23 October 1997.

\begin{abstract}
Where there is sufficient water storage in the soil the water potential $\left(\Psi_{x}\right)$ in shoots of Norway spruce [Picea abies (L.) Karst.] is strongly governed by the vapour pressure deficit of the atmosphere, while the mean minimum values of $\Psi_{x}$ usually do not drop below $-1.5 \mathrm{MPa}$ under meteorological conditions in Estonia. If the base water potential $\left(\Psi_{b}\right)$ is above $-0.62 \mathrm{MPa}$, the principal factor causing water deficiency in shoots of $P$. abies may be either limited soil water reserves or atmospheric evaporative demand depending on the current level of the vapour pressure deficit. As the soil dries the stomatal control becomes more efficient in preventing water losses from the foliage, and the leaf water status, in turn, less sensitive to atmospheric demand. Under drought conditions, if $\Psi_{b}$ falls below $-0.62 \mathrm{MPa}$, the trees' water stress is mainly caused by low soil water availability. Further declines in the shoot water potential (below $-1.5 \mathrm{MPa}$ ) can be attributed primarily to further decreases in the soil water, i.e. to the static water stress.
\end{abstract}

Key words. Hydrology (evapotranspiration · plant ecology $\cdot$ soil moisture).

\section{Introduction}

By far the largest fraction of terrestrial evaporative water loss passes through the stomatal pores of plant leaves. It is estimated that this pathway accounts for $70 \%$ of the evaporative vapour loss in Europe (Maniak, 1988; cited by Körner, 1994), and similar values may apply to other regions. The transfer of water in the soilplant-atmosphere continuum is considered a catenary process driven by water potential gradient in the system. The pathway of water movement through this continuum represents a hydraulic system containing several resistances to the flow of water (Passioura, 1982; Boyer,
1985; Nobel, 1991). The flow of water along a series of resistances requires a difference in water potentials and this difference is largest when the flow is largest and where the resistance is highest. Plants act as an interface bridging the steep water potential difference between soil and atmosphere.

Soil water potential is a relatively stable characteristic in comparison with that of the atmosphere, which can vary both diurnally and seasonally within a wide range (Kramer and Boyer, 1995; Larcher, 1995). Thus, the rate of water transfer through the soil-plant-atmosphere continuum is mainly determined by atmospheric evaporative demand. However, plants do not represent merely a passive link between the soil and the atmosphere; vegetation, their control of evapotranspiration through stomatal regulation, feeds back on the climate and soil moisture regime. Thereby, the plant water potential depends on the ratio of the water loss from the foliage to its absorption by roots.

The water balance of a plant becomes negative as soon as the uptake of water is insufficient to meet the requirements of transpiration, causing the plant water potential to decline. The plant water stress can be divided into static stress caused by low water availability in the soil, and dynamic stress resulting from the resistance to water flow through the plant due to transpirational water loss from foliage (Tyree and Ewers, 1991). The dynamics of the leaf water potential $\left(\Psi_{x}\right)$ is sometimes treated as a sum of two components (Hinckley and Ritchie, 1973; Lassoie et al., 1983; Pothier et al., 1989). These are base level water potential (base potential, $\Psi_{b}$ ) and diurnal depression from the base level (depression potential, $\Psi_{d}$ ):

$\Psi_{x}=\Psi_{b}+\Psi_{d}$.

$\Psi_{b}$, measured just before dawn, when the water content of leaves and soil is presumed to be in equilibrium, should express the static water stress; $\Psi_{d}$ indicates the level of the dynamic water stress.

We examined the dynamics of the water potential in shoots (hereafter shoot water potential) of Norway spruce [Picea abies (L.) Karst.], one of the main tree 
species in northern Europe, to investigate its dependence on the air and soil water status. In Estonia, pure spruce stands and mixed forests with spruce dominance make up $20 \%$ of the total area of woodlands, and $26 \%$ of the total forest yield (Valk and Eilart, 1974). The annual amount of precipitation in Estonia is sufficient for plant growth, however, in some years both field crops and forest trees may suffer from water deficit due to uneven distribution of precipitation throughout the growing period. The growth and productivity of trees is largely dependent on their water relations (Badot et al., 1990; Alavi, 1996; Bréda and Granier, 1996), as water stress may cause a marked reduction in growth and development. In Estonia, precipitation and air temperature together determine up to $40 \%$ of the total variation in the radial increment of spruce trees (Kask, 1992).

The objective of the present study is to elucidate the role of soil drought versus atmospheric evaporative demand in the development of trees' water stress.

\section{Materials and methods}

\subsection{Study site}

Experimental work was done at Vooremaa Ecology Station $\left(58^{\circ} 44^{\prime} \mathrm{N}, 26^{\circ} 45^{\prime} \mathrm{E}\right)$, Estonia, from June to August in 1994-1996. The annual precipitation in the Vooremaa area ranges from 600 to $630 \mathrm{~mm}, 400$ to 410 $\mathrm{mm}$ of this amount falling during the growing season, i.e. during the period when the mean diurnal air temperature is above $+5^{\circ} \mathrm{C}$. The mean monthly air temperature ranges between $-6.6^{\circ}$ and $+17.3^{\circ} \mathrm{C}$. The annual total radiation budget averages $1273 \mathrm{MJ} \mathrm{m}^{-2}$ (Russak, 1990).

The study area was situated in a natural uneven-aged Picea abies stand with single trees of Betula pendula Roth, Ouercus robur L. and Populus tremula L. The soil was a rich well-drained brown forest soil (Calcaric Cambisol according to FAO classification) formed on red-brown calcareous moraine. Earlier studies conducted in Vooremaa region (Lykhmus et al., 1986) indicated that the forest litter layer and the upper $10 \mathrm{~cm}$ of the mineral soil comprised $49 \%$, and the layer at $10-20 \mathrm{~cm}$ depth $23 \%$ of the absorbing roots; the deeper layer had significantly less of the total mass of absorbing roots in brown forest soil. The $\mathrm{pH}_{\mathrm{H}_{2} \mathrm{O}}$ of the rooted zone was 5.2. A detailed description of the climate, soil and vegetation of the study area has been previously published (Frey, 1977).

\subsection{Pressure chamber measurements}

Measurements were carried out on 30- to 40-year-old relatively freely growing trees, with crowns exposed to the east and the south. The height of the sample trees was 11.5 to $12.7 \mathrm{~m}$. The bulk water potential $\left(\Psi_{x}\right)$ was measured by the balancing pressure technique using a Scholander-type pressure chamber (Boyer, 1995). $\Psi_{x}$ was determined on current-year shoots cut from the middle third of the crown's shaded side in order to minimize the variation in $\Psi_{x}$ caused by direct radiation. Earlier measurements have revealed that there may be differences in $\Psi_{x}$ amounting up to $0.35 \mathrm{MPa}$ between shaded and exposed shoots of $P$. abies on sunny summer days (unpublished data). On each day of observation, six shoots were sampled just before sunrise (i.e. 0330 to $0430 \mathrm{~h}$ ), and after that at two-hourly intervals from 0600 to 2200 h, East European standard time. If current-year shoots were too small for the chamber, samples consisting of both current- and previous-year shoots were used.

As the trees differed in height, sample shoots were situated at various heights above the ground. To eliminate a variation in $\Psi_{x}$ due to height, the gravitational component of water potential was subtracted from the values obtained with the pressure chamber. The gravitational potential was calculated from the height of the sampled shoots above the ground surface. No correction was made for the solute potential of the xylem sap, as it was considered negligible (Hellkvist et al., 1974).

\subsection{Soil and atmospheric characteristics}

Three replicate soil cores were collected daily with a manual soil borer at depths of 0-10, 10-20, 20-30 and $30-40 \mathrm{~cm}$. The total soil water content $(\theta)$ was determined gravimetrically by drying soil samples at $102{ }^{\circ} \mathrm{C}$ and was expressed as a percentage of soil dry weight. Available soil water storage $\left(W_{t r}\right)$, defined as the one available for transpiration and expressed in $\mathrm{mm}$ per $10 \mathrm{~cm}$ soil layer, appeared to be a soil water characteristic most relevant to base water potential in $P$. abies (Sellin, 1996). It was calculated as follows:

$W_{t r}=\rho_{s} \cdot\left(\theta-1.5 W_{m h}\right)$,

where $\rho_{s}$ is the soil bulk density $\left(\mathrm{g} \mathrm{cm}^{-3}\right.$ and $W_{m h}$, the maximum soil hygroscopicity $(\%)$, both determined separately for each depth. $W_{m h}$ was determined according to the Nikolayev method (Kitse and Rooma, 1984): air-dry soil samples were allowed to saturate in a desiccator above a saturated solution of $\mathrm{K}_{2} \mathrm{SO}_{4}$, ovendrying weighing procedure followed.

Relative humidity and temperature of the air were recorded simultaneously with the pressure chamber measurements using an aspirated Assmann psychrometer.

\subsection{Analysis of results}

A daily maximum level of $\Psi_{x}$, measured early in the morning and presumed to correspond to the condition of equilibrium between soil and plant water potentials, was always defined as the base potential $\left(\Psi_{b}\right)$ despite the time of observation (Sellin, 1996). Depression potential $\left(\Psi_{d}\right)$ was expressed as a difference between the current level of $\Psi_{x}$ and $\Psi_{b}$. Relative humidity and temperature data were used to calculate vapour pressure deficit of the 
atmosphere (VPD) as a measure of the atmospheric evaporative demand. Relationships between the components of shoot water potential and environmental variables were evaluated using non-linear regression procedure based on the least squares method. To approximate the relationships of non-linear character, functions giving the best fit in terms of coefficient of determination $\left(R^{2}\right)$ and standard error of estimate (SEE) were chosen. To evaluate the role of soil drought versus atmospheric evaporative demand in the development of trees' water stress, an empirical model predicting the daily evolution of $\Psi_{x}$ from the current vapour pressure deficit and $\Psi_{b}$ (taken as an index of the soil water availability) was developed.

\section{Results}

The base water potential in the shoots of Picea abies correlated well with $W_{t r}$ at the depth of 30-40 cm, which explained $77 \%$ of the variation in $\Psi_{b}$. The best fit resulted from the application of the following hyperbolic function:

$$
\Psi_{b}=-0.119-\frac{12.0}{W_{t r}^{1.72}}, R^{2}=0.768, S E E=0.062,
$$

where $\Psi_{b}$ is the base water potential (MPa) and $W_{t r}$, the available soil water storage $(\mathrm{mm})$. The relationship between $\Psi_{b}$ and the soil water availability for Norway spruce, at least in the summer period, was of asymptotic nature: $\Psi_{b}$ was independent of the soil water storage if $W_{t r}$ was over $15 \mathrm{~mm}$ and decreased hyperbolically if $W_{t r}$ dropped below this value (Fig. 1). The relationships between $\Psi_{b}$ and $W_{t r}$, measured at other depths, were remarkably weaker (Table 1). Thus, below a certain level of available water in the soil, $\Psi_{b}$ may be used as an index of soil water status.

The daily values of $\Psi_{d}$ decreased with increasing VPD, while the relationship can be approximated as follows (Fig. 2):

$$
\begin{gathered}
\Psi_{d}=-0.509\left(1-e^{-5.08 \cdot V P D^{1.52}}\right), \\
R^{2}=0.464, S E E=0.177,
\end{gathered}
$$

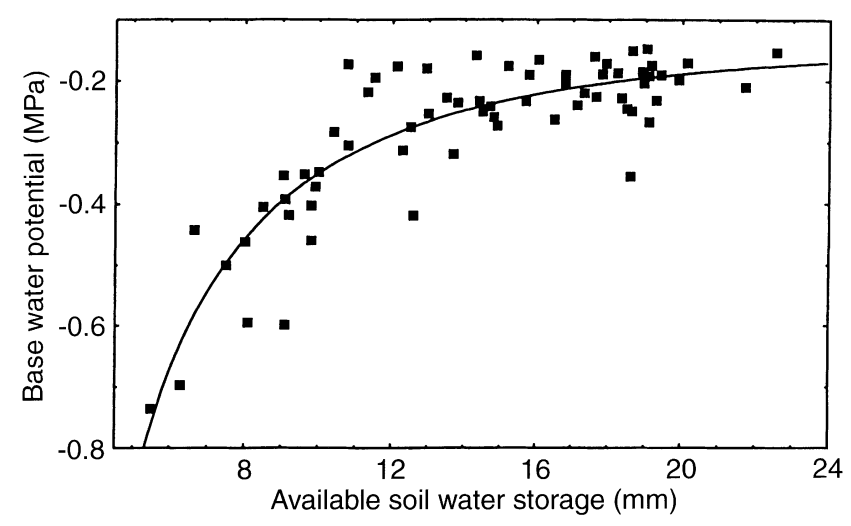

Fig. 1. The base water potential $\left(\Psi_{b}\right)$ of shoots versus available soil water storage $\left(W_{t r}\right)$ at the depth of $30-40 \mathrm{~cm}$
Table 1. Coefficients of determination $\left(R^{2}\right)$ and standard errors of estimate $(S E E)$ for the regressions of base water potential from available soil water storage $\left(\Psi_{b}=a+b /\left(W_{t r}^{c}\right)\right)$

\begin{tabular}{llll}
\hline $\begin{array}{l}\text { Soil depth } \\
\text { layer, cm }\end{array}$ & $\begin{array}{l}\text { Number of } \\
\text { observations }\end{array}$ & $\begin{array}{l}\text { Coefficient of } \\
\text { determination }\end{array}$ & $\begin{array}{l}\text { Standard error } \\
\text { of estimate }\end{array}$ \\
\hline $0-10$ & 50 & 0.469 & 0.101 \\
$10-20$ & 71 & 0.693 & 0.072 \\
$20-30$ & 50 & 0.752 & 0.069 \\
$30-40$ & 71 & 0.768 & 0.062 \\
\hline
\end{tabular}

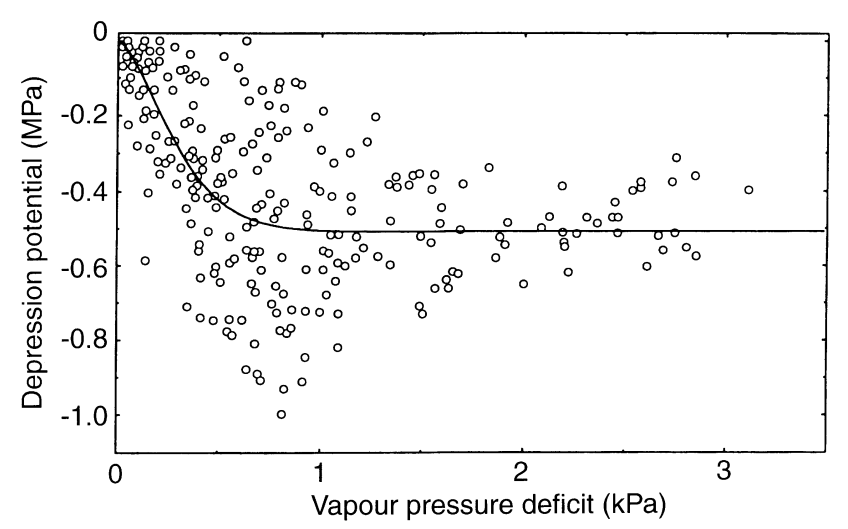

Fig. 2. The depression potential $\left(\Psi_{d}\right)$ of shoots versus current vapour pressure deficit of the atmosphere (VPD)

where VPD is the current vapour pressure deficit of the atmosphere $(\mathrm{kPa})$. VPD alone explained only $46 \%$ of the variability in $\Psi_{d}$, while the daily values of the bulk water potential $\left(\Psi_{x}\right)$ were more closely $\left(R^{2}=0.643\right)$ related to vapour pressure deficit of the atmosphere. Studying the influence of the soil water availability on the parameters of Eq. (4) indicated that the second parameter (equal to -5.08 in the regression equation) was most sensitive to soil humidity. As there was a strong correlation between $\Psi_{b}$ and $W_{t r}$, the second parameter was replaced with a function of $\Psi_{b}$ and all parameters were re-estimated:

$\Psi_{d}=-0.616\left(1-e^{\frac{0.2911 D^{1.15}}{\Psi_{b}+0.0933}}\right), R^{2}=0.593, S E E=0.154$

The application of $\Psi_{b}$ as an additional independent variable improved significantly the approximation of $\Psi_{d}$ from VPD (Eq. 5). The variation in depression potential depending on the base water potential and vapour pressure deficit of the atmosphere is illustrated in Fig. 3.

The addition of $\Psi_{b}$ and $\Psi_{d}$ (Eq. 1) resulted in an empirical model explaining the combined effect of soil water availability and atmospheric evaporative demand on shoot water potential (Fig. 4):

$$
\begin{array}{r}
\Psi_{x}=\Psi_{b}-0.616\left(1-e^{\frac{0.291 V P D^{1.15}}{\Psi_{b}+0.0933}}\right) \\
R^{2}=0.708, S E E=0.154
\end{array}
$$

The current vapour pressure deficit and base water potential combined accounted for $71 \%$ of the total vari- 


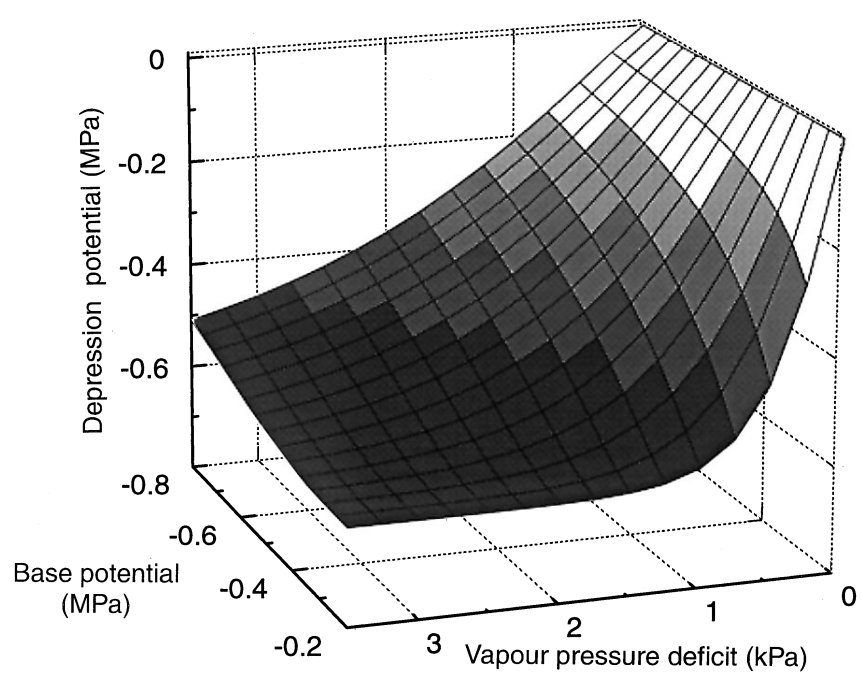

Fig. 3. Variation in depression potential $\left(\Psi_{d}\right)$ depending on the base water potential $\left(\Psi_{b}\right)$ and vapour pressure deficit of the atmosphere (VPD). The means for the intervals of $\Psi_{d}$ indicated by consecutive tones from white to dark grey: $-0.11,-0.21,-0.31,-0.41$, and $-0.51 \mathrm{MPa}$

ability of the shoot water potential in the studied Norway spruce trees. The first coefficient $(-0.616)$ in the expression of the depression potential in Eq. (5) and (6) indicates the value of the asymptote, i.e. a theoretical minimum value of $\Psi_{d}$. Thus, if $\Psi_{b}$ is below $-0.62 \mathrm{MPa}$ (corresponds to $W_{t r}<6.4 \mathrm{~mm}$ at the depth of $30-40 \mathrm{~cm}$ ), the primary reason of trees' water stress is always the soil water deficiency.

In Fig. 4 it can be seen that increasing VPD had a stronger effect on the water status of the trees in the case of wet soil, causing a steeper decline in $\Psi_{x}$ as compared to drought conditions. Certain theoretical minimum

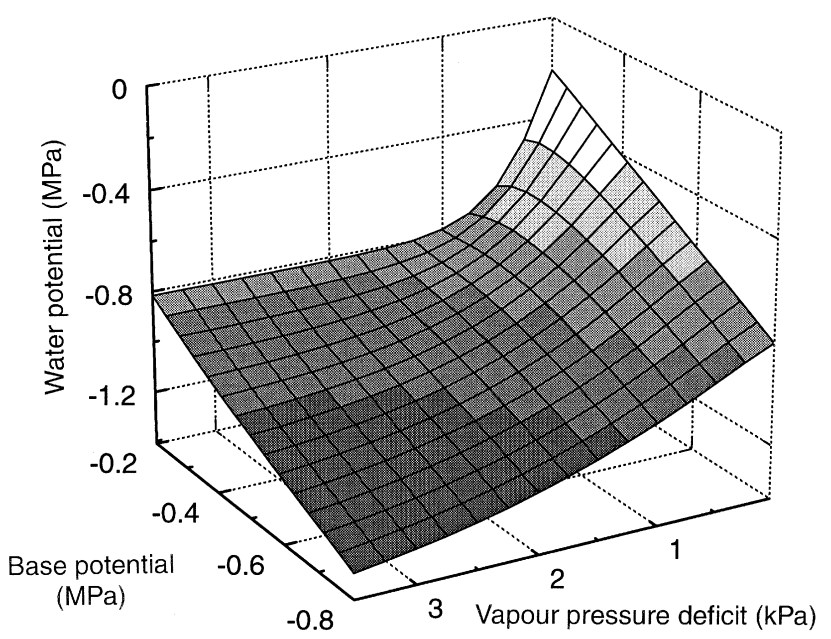

Fig. 4. The shoot water potential $\left(\Psi_{x}\right)$ as a function of the base water potential $\left(\Psi_{b}\right)$ and vapour pressure deficit (VPD). The means for the intervals of $\Psi_{x}$ indicated with the consecutive tones from white to dark grey: $-0.40,-0.58,-0.76,-0.94$, and $-1.12 \mathrm{MPa}$ values of $\Psi_{x}$ correspond to different levels of the soil water availability: the drier the soil, the lower the base water potential and the more negative values of $\Psi_{x}$ will be observed. Proceeding from the empirical data and using the model derived, one can predict the level of atmospheric evaporative demand causing $\Psi_{x}$ to approach the minimum (Table 2).

$\Psi_{b}$ occurs in both terms of Eq. (6), while its influence (i.e. impact of the soil water availability) on shoot water status is of dual nature. On the one hand (the first term), the lower the $\Psi_{b}$, the smaller (more negative) the $\Psi_{x}$. On the other hand (the second term), the lower the $\Psi_{b}$, the smaller the absolute value of the diurnal depression (Fig. 3 ) and the larger (less negative) the $\Psi_{x}$.

Depending on the combination of air and soil humidities, different patterns in the daily dynamics of the shoot water potential were observed and are illustrated in Fig. 5.

1. Under high soil water availability $\left(W_{t r}>15 \mathrm{~mm}\right.$ at the reference depth) and low atmospheric evaporative demand $(\mathrm{VPD}<0.9 \mathrm{kPa})$ the dynamics of $\Psi_{x}$ was controlled by VPD: $\Psi_{x}$ followed closely the current level of VPD throughout the day (Fig. 5A).

2. Under high soil water availability and high atmospheric evaporative demand (VPD $>0.9 \mathrm{kPa}) \Psi_{x}$ decreased with increasing VPD up to a certain level about midday, while a further increase in VPD after midday was accompanied by an increase in $\Psi_{x}$. In the afternoon $\Psi_{x}$ matched the changes in VPD as well, but demonstrated a marked hysteresis (Fig. 5B).

3. When the soil condition reached drought $\left(W_{t r}<\right.$ $10 \mathrm{~mm}$ ), accompanied usually by very dry air in the daytime $(\mathrm{VPD}>2 \mathrm{kPa}), \Psi_{x}$ was coupled with the evolution of VPD only in the morning. After midday $\Psi_{x}$ did not match VPD and no noticeable recovery of $\Psi_{x}$ could be observed before night fall (Fig. 5C).

Thus, the impact of atmospheric evaporative demand on shoot water supply weakened significantly with increasing water deficiency in the soil, and this may be attributed to more efficient stomatal control on transpirational water loss from foliage. The threshold values of the shoot water potential, inducing a stomatal closure (judged by the onset of $\Psi_{x}$ recovery at continuing increase in VPD) at midday, decreased with decreasing soil water level (Fig. 6).

Table 2. Theoretical minimum values of the shoot water potential $\Psi_{\min }$ and the corresponding atmospheric evaporative demands (VPD) causing water potential to approach the minimum value predicted from the model for different levels of the soil water status $\left(\Psi_{b}\right)$

\begin{tabular}{lll}
\hline$\Psi_{b}, \mathrm{MPa}$ & $\Psi_{\text {min }}, \mathrm{MPa}$ & $\mathrm{VPD}, \mathrm{kPa}$ \\
\hline-0.1 & -0.72 & 0.10 \\
-0.2 & -0.82 & 1.09 \\
-0.4 & -1.02 & 2.72 \\
-0.6 & -1.22 & 4.21 \\
-0.8 & -1.42 & 5.62 \\
\hline
\end{tabular}



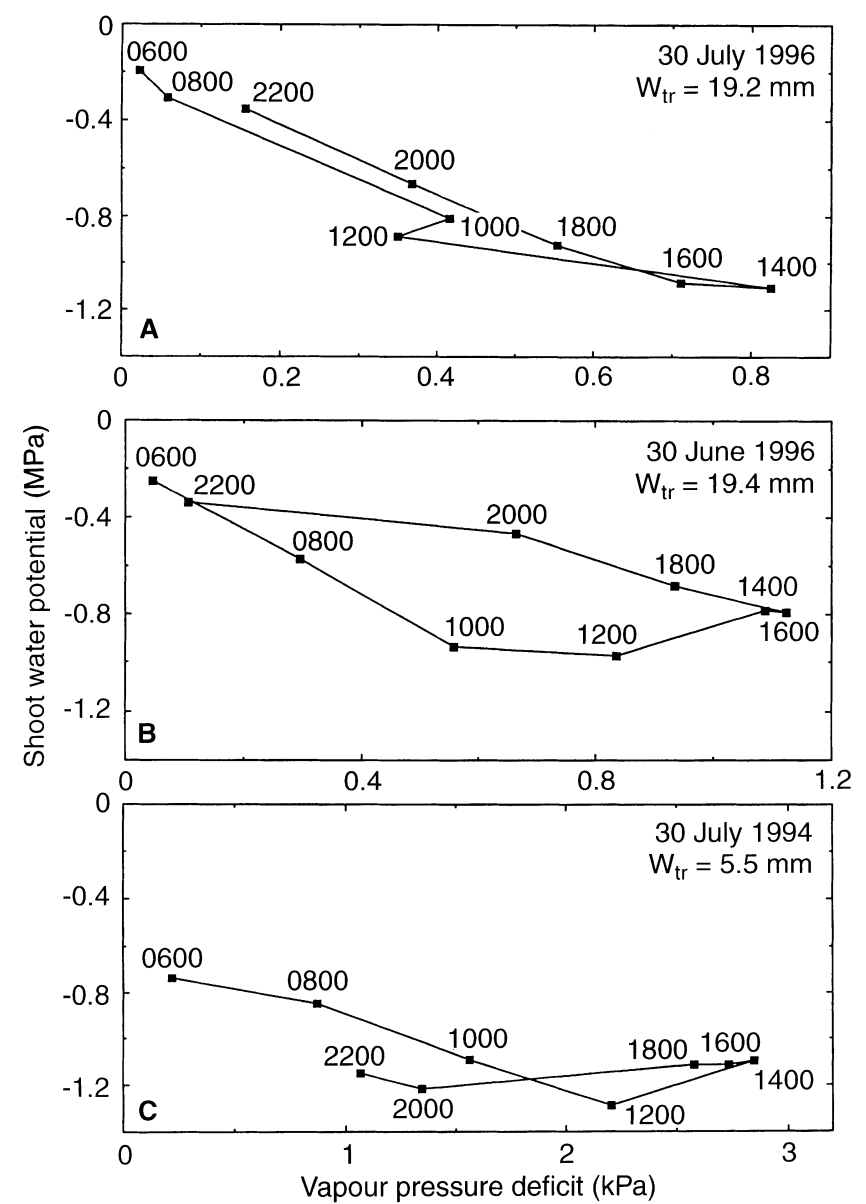

Fig. 5A-C. Daily patterns of the shoot water potential depending on the combination of air and soil conditions. A high soil water availability and low atmospheric evaporative demand; $\mathbf{B}$ high soil water availability and high atmospheric evaporative demand; $\mathbf{C}$ low soil water availability and high atmospheric evaporative demand. Note, the horizontal axes for $\mathbf{A}, \mathbf{B}$ and $\mathbf{C}$ are different

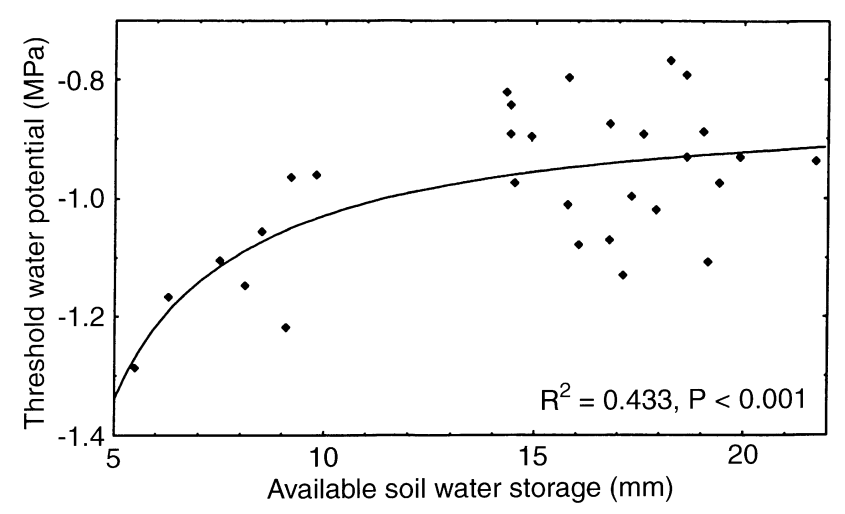

Fig. 6. The threshold values of the shoot water potential inducing a stomatal closure at midday versus available soil water storage at the depth of $30-40 \mathrm{~cm}$

\section{Discussion and conclusions}

There was a good correlation between $\Psi_{b}$ and the available soil water storage at the depth of $30-40 \mathrm{~cm}$, which explained $77 \%$ of the variation in $\Psi_{b}$ in the shoots of Picea abies. The relationship between soil water storage and $\Psi_{b}$ for Norway spruce was of asymptotic nature (Fig. 1): $\Psi_{b}$ was independent of the soil water level if $W_{t r}$ was over $15 \mathrm{~mm}$ and decreased hyperbolically if $W_{t r}$ dropped below this value. A similar pattern of variation in $\Psi_{b}$, depending on the soil water content, has been described for other conifers (Hinckley and Ritchie, 1973; Aussenac et al., 1984) as well as broad-leaved tree species (Thompson and Hinckley, 1977; Garnier and Berger, 1987; Bréda et al., 1995). Thus, $\Psi_{b}$ can be used as an index of soil water status, but it becomes more responsive under dry soil conditions.

The fact that $\Psi_{b}$ was most closely related to $W_{t r}$ at the depth of $30-40 \mathrm{~cm}$ (Table 1) was to some extent unexpected, because most of the active root system in Norway spruce trees growing in brown forest soil is superficial (Lykhmus et al., 1986). Bishop and Dambrine (1995) demonstrated that the main water uptake by spruce trees in a podsolized forest soil comes from the zone ranging from the mor layer to $5 \mathrm{~cm}$ below the mormineral soil contact. This apparent discord can be explained by the following facts. Firstly, there is a high spatial and temporal variability in water content of the upper soil layers, while deeper layers are more homogeneous in this respect. Secondly, lowered water absorption by superficial roots due to drying of upper soil horizons can be compensated by deeper roots, the contribution of which to the total water uptake increases during a soil drying cycle. The $\Psi_{b}$ is determined by the water status of the wettest rooted zone rather than that of the main localization of the absorbing roots (Bréda et al., 1995; Hinckley et al., 1978; Sala et al., 1981).

The daily values of the shoot water potential in $P$. abies were closely related to vapour pressure deficit of the atmosphere: VPD explained $64 \%$ of the diurnal variation in $\Psi_{x}$. The daily dynamics of leaf water potential in several other European woody species are also strongly governed by atmospheric evaporative demand (Matejka and Huzulák, 1984; Huzulák and Matejka, 1986; Linnenbrink et al., 1992). Our results indicated that the daily pattern of shoot water potential reflects interaction between changing soil water supplies and atmospheric evaporative demands. If $\Psi_{b}$ is above $-0.62 \mathrm{MPa}$, the principal factor causing the water deficiency in the shoots of $P$. abies may be either limited soil water reserves or evaporative demand depending on the current level of the vapour pressure deficit. Under drought conditions, if $\Psi_{b}$ falls below this value, the tree's water stress is primarily caused by low soil water availability. The empirical model (Eq. 6) derived for predicting $\Psi_{x}$ from the current vapour pressure deficit and base water potential described $71 \%$ of the total variability of the shoot water potential in the studied Norway spruce trees.

The amount of variance explained by this model $\left(R^{2}=0.71, S E E=0.15 \mathrm{MPa}\right)$ is comparable with that of similar models proposed for other species. Pothier et al. (1989) presented a model for dynamics of $\Psi_{x}$ in Picea mariana (Mill.) BSP depending on potential evapotranspiration as a measure of the atmospheric evaporative demand. The latter explained $79 \%$ of the variation in $\Psi_{x}$ 
on separate days, but $R^{2}$ was improved to 0.87 if pre-dawn water potential was added to the model. The atmospheric evaporative demand and soil moisture together have been reported to explain $25-53 \%$ of the variation in daily minimum water potential in the leaves of Eucalyptus microtheca F. Muell. (Tuomela and Kanninen, 1995) and $77 \%$ in those of Quercus species (Badot et al., 1994). The probable error of the analogical model derived for three shrub species by Huzulák and Matejka (1983) varied within the range of $0.09-0.12 \mathrm{MPa}$. Thompson and Hinckley (1977) described a model which simulated $\Psi_{x}$ for Quercus alba L., using soil moisture content, VPD and solar radiation (set to be non-limiting) as input variables. The average residual error of $\Psi_{x}$ ranged from 0.03 to $0.26 \mathrm{MPa}$ for different test days.

The sensitivity of trees' water status to the atmospheric evaporative demand depended on the soil water availability (Fig. 4). Depending on the combination of air and soil humidities different patterns in the daily dynamics of the shoot water potential can be observed. In cases of wet soil, the shoot water potential decreases quickly with increasing VPD, while the daily course of $\Psi_{x}$ is coupled with the current level of the evaporative demand (Fig. 5A). Under high water availability in the soil, minimum $\Psi_{x}$ can be reached at low levels of VPD already (Table 2). After $\Psi_{x}$ has fallen to a certain level $(-0.8$ to $-1.2 \mathrm{MPa})$, the stomata will significantly narrow and a further rise in VPD after midday will be accompanied by an increase in $\Psi_{x}$ (Fig. 5B). The decline of leaf water potential below certain threshold values and/or transpiration rate attained to a high level induce fast turgor changes in guard cells (Franks et al., 1997), which cause stomatal closure to avoid further dehydration leading to the xylem dysfunction through run-away embolism. In contrast to that, under drought conditions $\Psi_{x}$ declines slowly (Fig. 4), giving evidence of weakening of the impact of the evaporative demand on shoot water supply due to more efficient stomatal control on transpirational water loss from the foliage. The correlation between stomatal conductance and $\Psi_{b}$ in $P$. abies has been confirmed by Cienciala et al. (1994) and Lu et al. (1995). At low soil water availability $\Psi_{x}$ is coupled with VPD only in the morning. Reaching a threshold value about midday, $\Psi_{x}$ causes the onset of stomatal closure, preventing its further decline. After midday $\Psi_{x}$ does not vary with VPD and no noticeable recovery of $\Psi_{x}$ can be observed before nightfall (Fig. 5C). The increase of hydraulic resistance in the soil-root interface (Barataud et al., 1995) and probably in the xylem as well (Sellin, 1991) reduces water transport to leaves and makes fast recovery of $\Psi_{x}$ impossible under severe drought conditions. The threshold value of $\Psi_{x}$, inducing a stomatal closure, decreases with decreasing soil water level (Fig. 6).

With increasing VPD, the water supply for leaves lags increasingly behind the transpirational water losses, causing $\Psi_{x}$ in leaves to decline. Our results revealed a clear pattern: the lower the soil water availability, the smaller the $\Psi_{d}$ and the less the the daily amplitude of $\Psi_{x}$ (Fig. 3). The same fact has been stated concerning other conifers (Lassoie et al., 1983) as well as hardwoods (Huzulák and Matejka, 1986; Sasse and Sands, 1996): although the minimum $\Psi_{x}$ reached during a day decreased as the soil dried, the differences between minimum $\Psi_{x}$ and $\Psi_{b}$ diminished. As soil water decreases, stomata will close more, preventing lethal diurnal depression in leaf water potential. Franco et al. (1994) reported for Larrea tridentata (D.C.) Cov. that the lower the pre-dawn xylem water potential, the weaker the effect of VPD on stomatal conductance. Soil drying stimulates the production of chemical signals in the roots, which are transferred via transpiration stream to the shoot. Chemical and/or hydraulic signals springing from the root system trigger osmotic adjustment of the leaf cells, modulating thus the opening capacity of the stomatal pores (Jackson et al., 1995; Liang et al., 1996; Tardieu et al., 1996), allowing needles to tolerate increasingly more negative water potentials, stomata remaining open thereby. Of course, other physiological mechanisms may be involved in the trees' acclimation to drought as well. Zine E1 Abidine et al. (1994) found that drought preconditioning enabled seedlings of Picea mariana (Mill.) BSP to maintain a substantially higher level of stomatal conductance and photosynthesis during a severe water stress as compared to unconditioned seedlings, but this effect was not accompanied by any changes in the concentration of osmotically active solutes.

To summarize, where there is sufficient water storage in the soil the shoot water potential of Norway spruce is strongly governed by the vapour pressure deficit of the atmosphere, while the mean minimum values of $\Psi_{x}$ usually do not drop below $-1.5 \mathrm{MPa}$ under meteorological conditions prevailing in Estonia. As the soil dries the stomatal control becomes more efficient in preventing water losses from the foliage, and the leaf water status, in turn, less sensitive to atmospheric evaporative demand. Further decrease in the shoot water potential (below $-1.5 \mathrm{MPa}$ ) can be attributed primarily to a decrease in soil water, i.e. to the static water stress. Thus, the trees' responsiveness to atmospheric factors is determined by the soil water availability.

Acknowledgement. This study was supported by a grant from the Estonian Science Foundation. I am grateful to Mr. Margus Pensa for technical assistance in field studies and to Mrs. Krista Kallis for improving the English text.

Topical Editor J.-P. Duvel thanks P. Viterbo and another referee for their help in evaluating this paper.

\section{References}

Alavi, G. Radial stem growth of Picea abies in relation to spatial variation in soil moisture conditions, Scand. J. For. Res., 11, 209-219, 1996.

Aussenac, G., A. Granier, and M. Ibrahim, Influence du dessèchement du sol sur le fonctionnement hydrique et la croissance du douglas (Pseudotsuga menziesii (Mirb.) Franco), Acta Oecol. Oecol. Plant., 5, 241-253, 1984.

Badot, P. M., P. Perrier, and M. J. Badot, Dépérissement, déficit hydrique et variations de croissance radiale chez le Picea abies, Can. J. Bot., 68, 1536-1541, 1990.

Badot, P.-M., É. Lucot, and S. Bruckert, L'humidité du sol en profondeur constitue, en milieu de journée, la principale source de variation du potentiel hydrique foliaire de peuplements de Chêne (Quercus sp.), C.R. Acad, Paris. Sci., 317, 341-345, 1994. 
Barataud, F., C. Moyne, N. Bréda, and A. Granier, Soil water dynamics in an oak stand. 2. A model of the soil-root network compared with experimental data, Plant Soil, 172, 29-43, 1995.

Bishop, K., and E. Dambrine, Localization of tree water uptake in Scots pine and Norway spruce with hydrological tracers, Can. J. For. Res., 25, 286-297, 1995.

Boyer, J. S., Water transport, Ann. Rev. Plant Physiol., 36, 473516, 1985

Boyer, J. S., Measuring the Water Status of Plants and Soils, Academic Press, San Diego, 1995.

Bréda, N., and A. Granier, Intra- and interannual variations of transpiration, leaf area index and radial growth of a sessile oak stand (Quercus petraea), Ann. Sci. For., 53, 521-536, 1996.

Bréda, N., A. Granier, F. Barataud, and C. Moyne, Soil water dynamics in an oak stand. 1. Soil moisture, water potentials and water uptake by roots, Plant Soil, 172, 17-27, 1995.

Cienciala, E., A. Lindroth, J. Cermák, J.-E. Hällgren, and J. Kučera, The effects of water availability on transpiration, water potential and growth of Picea abies during a growing season, $J$. Hydrol., 155, 57-71, 1994.

Franco, A. C., A. G. de Soyza, R. A. Virginia, J. F. Reynolds, and W. G. Whitford, Effects of plant size and water relations on gas exchange and growth of the desert shrub Larrea tridentata, Oecologia, 97, 171-178, 1994.

Franks, P. J., I. R. Cowan, and G. D. Farquhar, The apparent feedforward response of stomata to air vapour pressure deficit: information revealed by different experimental procedures with two rainforest trees, Plant, Cell Environ., 20, 142-145, 1997.

Frey, T. (Ed), Spruce Forest Ecosystem Structure and Ecology. 1. Introductory Data on the Estonian Vooremaa Project, Acad. Sci. ESSR, Tartu, 1977.

Garnier, E., and A. Berger, The influence of drought on stomatal conductance and water potential of peach tress growing in the field, Sci. Hort., 32, 249-263, 1987.

Hellkvist, J., G. P. Richards, and P. G. Jarvis, Vertical gradients of water potential and tissue water relations in Sitka spruce trees measured with the pressure chamber, J. Appl. Ecol., 11, 637668, 1974.

Hinckley, T. M., and G. A. Ritchie, A theoretical model for calculation of xylem sap pressure from climatological data, Am. Midl. Nat. 90, 56-69, 1973.

Hinckley, T. M., J. P. Lassoie, and S. W. Running, Temporal and spatial variations in the water status of forest trees, For. Sci. Monog., 20, 1-72, 1978.

Huzulák, J., and F. Matejka, A model for the leaf water potential daily dynamics of dominant shrub species in an oak-hornbeam forest, Biológia (Bratislava), 38, 411-418, 1983.

Huzulák, J., and F. Matejka, Determination of soil moisture causing plateau on the curve of leaf water potential daily course, Biológia (Bratislava), 41, 47-55, 1986.

Jackson, G. E., J. Irine, J. Grace, and A. A. M. Khalil, Abscisic acid concentrations and fluxes in droughted conifer saplings, Plant, Cell Environ., 18, 13-22, 1995.

Kask, P., Climate-radial increment relationships in Estonian conifer stands, Proc. Estonian Acad. Sci. Ecol., 2, 22-27, 1992.

Kitse, E., and I. Rooma, Laboratory course of soil science, Eesti Põlluumajanduse Akadeemia, Tartu, 1984. (in Estonian)

Körner, Ch., Leaf diffusive conductances in the major vegetation types of the globe, Ecophysiology of Photosynthesis, SpringerVerlag, Berlin Heidelberg New York, 463-490, 1994.

Kramer, P. J., and J. S. Boyer, Water Relations of Plants and Soils, Academic Press, San Diego, 1995.

Larcher, W., Physiological Plant Ecology, Springer-Verlag, Berlin Heidelbeg New York, 1995.
Lassoie, J. P., P. M. Dougherty, P. B. Reich, T. M. Hinckley, C. M. Metcalf, and S. J. Dina, Ecophysiological investigations of understory eastern redcedar in Central Missouri, Ecology, 64, $1355-1366,1983$.

Liang, J., J. Zhang, and M. H. Wong, Stomatal conductance in relation to xylem sap abscisic acid concentrations in two tropical trees, Acacia confusa and Litsea glutinosa, Plant, Cell Environ., 19, 93-100, 1996.

Linnenbrink, M., R. Lösch, and L. Kappen, Water relations of hedgerow shrubs in northern Central Europe. I. Bulk water relations, Flora, 187, 121-133, 1992.

Lu, P., P. Biron, N. Bréda, and A. Granier, Water relations of adult Norway spruce (Picea abies (L) Karst) under soil drought in the Vosges mountains: water potential, stomatal conductance and transpiration, Ann. Sci. For., 52, 117-129, 1995.

Lykhmus, K., R. R. Lasn, and T. A. Oja, Growth of the European spruce roots as related to soil conditions, Pochvovedeniye, 6, 89-97, 1986 (in Russian)

Maniak, U., Hydrologie und Wasserwirtschaft - Einführung für Ingenieure, Springer-Verlag, Berlin Heidelberg New York, 1988.

Matejka, F., and J. Huzulák, Dependence of the leaf water potential of forest trees on the atmospheric evaporative demand, Biológia (Bratislava), 39, 25-30, 1984.

Nobel, P S., Physicochemical and Environmental Plant Physiology, Academic Press, San Diego, 1991.

Passioura, J. B., Water in the soil-plant-atmosphere continuum, Encyclopedia of Plant Physiology. New Series, Springer-Verlag, Berlin Heidelberg New York, 12B, 5-33, 1982.

Pothier, D., M. Bédard, R. Caissy, and J. Stein, Variations du potentiel hydrique de plants d'épinette noire en pépiniére en fonction de variables météorologiques, Nat. Can., 116, 61-68, 1989.

Russak, V., Solar radiation, Climate of Tartu and its changes during the recent decades, Eesti TA Astrofüüsika ja Atmosfäärifüüsika Instituut, Tartu, 51-78, 1990 (in Estonian)

Sala, O. E., W. K. Lauenroth, W. J. Parton, and M. J. Trilica, Water status of soil and vegetation in a shortgrass steppe, Oecologia, 48, 327-331, 1981.

Sasse, J., and R. Sands, Comparative responses of cuttings and seedlings of Eucalyptus globulus to water stress, Tree Physiol., 16, 287-294, 1996.

Sellin, A., Hydraulic conductivity of xylem depending on water saturation level in Norway spruce (Picea abies (L.) Karst.), J. Plant Physiol., 138, 466-469, 1991.

Sellin, A., Base water potential of Picea abies as a characteristic of the soil water status, Plant Soil, 184, 273-280, 1996.

Tardieu, F., T. Lafarge, and T. Simonneau, Stomatal control by fed or endogenous xylem ABA in sunflower: interpretation of correlation between leaf water potential and stomatal conductance in anisohydric species, Plant, Cell Environ., 19, 75-84, 1996.

Thompson, D. R., and T. M. Hinckley, A simulation of water relations of white oak based on soil moisture and atmospheric evaporative demand, Can. J. For. Res., 7, 400-409, 1977.

Tuomela, K., and M. Kanninen, Effects of vapour pressure deficit and soil water content on leaf water potential between selected provenances of Eucalyptus microtheca in an irrigated plantation, Eastern Kenya, Silva Fenn. 29, 217-224, 1995.

Tyree, M. T., and F. W. Ewers, The hydraulic architecture of trees and other woody plants, New Phytol., 119, 345-360, 1991.

Valk, U., and J. Eilart, Forests of Estonia, Valgus, Tallinn, 1974. (in Estonian)

Zine El Abidine, A., P. Y. Bernier, J. D. Stewart, and A. P. Plamondon, Water stress preconditioning of black spruce seedlings from lowland and upland sites, Can. J. Bot., 72, 1511-1518, 1994. 